\title{
Characterization of Nonhost Resistance of Arabidopsis to the Asian Soybean Rust
}

\author{
Marco Loehrer, Caspar Langenbach, Katharina Goellner, Uwe Conrath, and Ulrich Schaffrath \\ Department of Plant Physiology, RWTH Aachen University, D-52056 Aachen, Germany
}

Submitted 15 April 2008. Accepted 28 June 2008.

\begin{abstract}
Asian soybean rust (ASR), caused by Phakopsora pachyrhizi, is a devastating disease of soybean. We report the use of the nonhost plant Arabidopsis thaliana to identify the genetic basis of resistance to $P$. pachyrhizi. Upon attack by $P$. pachyrhizi, epidermal cells of wild-type Arabidopsis accumulated $\mathrm{H}_{2} \mathrm{O}_{2}$, which likely orchestrates the frequently observed epidermal cell death. However, even when epidermal cell death occurred, fungal hyphae grew on and infection was terminated at the mesophyll boundary. These events were associated with expression of PDF1.2, suggesting that $P$. pachyrhizi, an ostensible biotroph, mimics aspects of a necrotroph. Extensive colonization of the mesophyll occurred in Arabidopsis pen mutants with defective penetration resistance. Although haustoria were found occasionally in mesophyll cells, the successful establishment of biotrophy failed, as evidenced by the cessation of fungal growth. Double mutants affected in either jasmonic acid or salicylic acid signaling in the pen3-1 background revealed the involvement of both pathways in nonhost resistance (NHR) of Arabidopsis to P. pachyrhizi. Interestingly, expression of AtNHL10, a gene that is expressed in tissue undergoing the hypersensitive response, was only triggered in infected pen3-1 mutants. Thus, a suppression of $P$. pachyrhizi-derived effectors by $P E N 3$ can be inferred. Our results demonstrate that Arabidopsis can be used to study mechanisms of NHR to ASR.
\end{abstract}

Additional keywords: eds1-2, jarl-1, sid2-1.

Increasing human mobility facilitates spread of phytopathogenic organisms into new habitats. In their new environments, pests and pathogens face plant communities that are not adapted to them. Introduced pathogens may thus cause disastrous epidemics in new habitats. One recent example for such a scenario is the spread of aggressive Asian soybean rust (ASR) isolates to the New World. Soybean rust is caused by the basidiomycete fungus Phakopsora pachirhizi and has been known for decades in the Eastern Hemisphere. In 1914, the pathogen was first reported on the legume Pachyrhizus erosus by H. and P. Sydow (Koch et al. 1983). The pest started a world-wide journey from Taiwan and spread to Australia (presence reported in 1934), Africa (approved in 1978), and South America (reported in 1980) (Koch et al. 1983). In November 2004, P. pachyrhizi landed in the continental United States

Corresponding author: Ulrich Schaffrath; Telephone: +492418020100; Fax: +492418022181; E-mail: schaffrath@bio3.rwth-aachen.de

* The $e$-Xtra logo stands for "electronic extra" and indicates that Figures 1,2 , and 5 appear in color online.
(Stokstad 2004). ASR was found in 2005 on kudzu (Pueraria lobata) (Harmon et al. 2006), an immigrant weed that serves as an alternate host that enables the pathogen to overwinter in the soybean-free time of the year (Christiano and Scherm 2007). Since ASR aggressively defoliates fields of soybean, it has received top ranking for soybean diseases in the Americas. However, regional spread of ASR has, so far, been limited in North America, presumably due to low inoculum available in 2005 and dry weather conditions in 2006 (Christiano and Scherm 2007).

The genus Phakopsora contains about 80 species. Six species have been described that parasitize legumes, including $P$. pachyrhizi (Asian-Australian species) and P. meibomiae (tropicalLatin American species), which each have an exceptionally wide host range, including soybean (Ono et al. 1992). Natural infections with $P$. pachyrhizi, for example, have been reported in 31 species from 17 genera of legumes, and artificial infections have been successful on 60 plant species in 26 additional genera (Rytter et al. 1984). In addition to its wide host range, ASR's modus of direct penetration of the epidermis is a feature that is uncommon for rust uredospores, which mostly enter the leaf by producing appressoria over stomata. However, direct penetration is a feature of monokaryotic basidiospores, e.g., of the cowpea rust fungus Uromyces vignae (Heath 1997; Mellersh and Heath 2001).

Uredospores of $P$. pachyrhizi germinate and form appressoria even on artificial substrates such as dialysis membranes, confirming that plant-derived signals are not needed for these developmental steps. However, as the frequency of appressorium formation corresponded to the pore size of membranes, the involvement of thigmodifferentiation rather than chemodifferentiation has been suggested (Koch and Hoppe 1988). During penetration of soybean epidermal cells, a funnel-shaped structure was formed in the appressorium, providing a cellwall continuum with the penetration hyphae (Koch et al. 1983). The latter transversed the epidermis and entered the spongy mesophyll, leaving behind a disorganized, subsequently collapsing, epidermal cell. Penetration hyphae differentiated to form primary and secondary hyphae. Finally, haustorial mother cells were formed that introduced thin infection pegs into mesophyll cells, followed by haustorial initials and mature haustoria (Koch et al. 1983). The development of uredosori and uredospores completes the pathogenesis of $P$. pachyrhizi on susceptible soybean leaves.

ASR is currently managed by fungicides. However, development of fungicide-resistant ASR strains must be expected, and the economic costs of repeated fungicide treatments are not negligible. In addition, traditional breeding strategies so far only provided soybean varieties that withstood particular races of the fungus, and after their introduction to the field, these traits were soon overcome (Bonde et al. 2006; Hartman et al. 
2005; Twizeyimana et al. 2007). In order to identify novel potential resistance traits to ASR, we elucidated a nonhost resistance (NHR) response to the fungus. NHR confers durable protection to all genotypes of a given plant species against all races of a given pathogen species in natural as well as agricultural systems. Therefore, NHR could be considered a useful resource to improve crop resistance (Ellis 2006; Heath 2000; Mysore and Ryu 2004; Thordal-Christensen 2003).

Over the past decade, Arabidopsis thaliana has emerged as a valuable model to study NHR in plants (Holub and Cooper 2004; Yun et al. 2003). Recently, a series of penetration mutants (pen1, pen2, and pen3) were identified in the model plant Arabidopsis thaliana, allowing considerable progress towards understanding NHR. Each mutant enabled entry of nonhost powdery mildew pathogens into epidermal cells at a higher frequency. $P E N 1$ encodes a syntaxin that might play a role in vesicle trafficking to the plasma membrane (Assaad et al. 2004; Collins et al. 2003). PEN2 is a glycosyl hydrolase, while PEN3 represents an ABC transporter that seems to act cooperatively with PEN2. It has been proposed that PEN2 turns on an inactive precursor of an unknown metabolite that prevents fungal penetration after its release to the apoplast by action of PEN3 (Lipka et al. 2005; Stein et al. 2006). Finally, concomitant knock-out of pre- and postpenetration defense led to full compatibility between Arabidopsis and nonhost powdery mildew pathogens (Lipka et al. 2005).

Recently, the interaction of Arabidopsis with the stomatapenetrating cowpea rust fungus (Uromyces vignae) was developed as a model to study NHR against rusts (Mellersh and Heath 2003). Here, we present the novel interaction between Arabidopsis and the direct-penetrating rust fungus $P$. pachyrhizi, which will allow further insight into NHR of Arabidopsis against this aggressive, introduced pathogen. Additionally, the use of a model plant has helped to overcome the limitations of the soybean-ASR pathosystem. Thus, light microscopical and histochemical analyses were used to follow P. pachyrhizi infection in various Arabidopsis pen single and double mutants. In this way, we were able to successively eliminate particular components of the nonhost defense machinery, allowing us to move increasingly towards a compatible P. pachyrhizi-Arabidopsis interaction. Finally, we elucidated successful traits of the NHR repertoire of Arabidopsis that could potentially be genetically engineered into soybean crops to combat ASR.
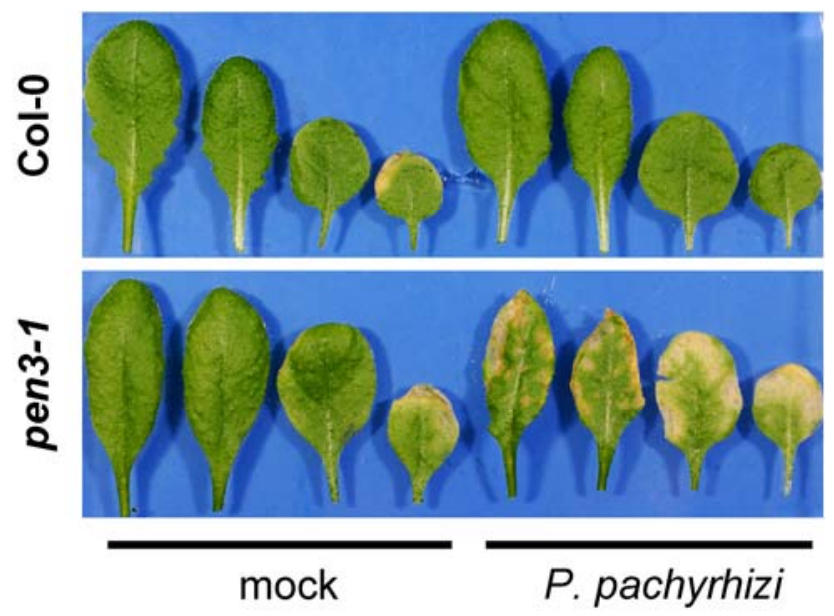

Fig. 1. The pen3-1 mutant of Arabidopsis shows macroscopic symptoms after infection with Phakopsora pachyrhizi. Representative leaves of wildtype (Col-0) plants (upper panel) and pen3-1 mutants (lower panel) were taken 10 days after inoculation with uredospores (right) or mock treatment (left).

\section{RESULTS}

Nonhost resistance to ASR in Arabidopsis.

In this work, we established a tractable ASR-Arabidopsis interaction in the lab that will allowed us to identify important components of the NHR of Arabidopsis to P. pachyrhizi. As expected from a bona fide nonhost plant, the pathogen did not cause macroscopic lesions or sporulate on any of the $28 \mathrm{Arabi}$ dopsis accessions tested in this study (a complete list can be found below). This finding confirmed that Arabidopsis can be regarded as a nonhost for ASR.

Next, we tested various Arabidopsis mutants with known defects in pathogen resistance. Of these, only pen3-1 displayed macroscopic disease symptoms in response to ASR infection (Fig. 1). Infected pen3-1 leaves initially became chlorotic and then turned necrotic (Fig. 1). Similar disease symptoms have been reported for pen3-1 after infection with other pathogens, including Phytophthora infestans and Botrytis cinerea (Stein et al. 2006).

\section{Cytology of the ASR-Arabidopsis interaction.}

To investigate the interaction between ASR and Arabidopsis at the cellular level, leaves of Arabidopsis plants infected with $P$. pachirhizi were stained with trypan blue before microscopy. After germination, the fungus penetrated epidermal leaf cells directly (Fig. 2A and B). This behavior contrasts markedly with that of the majority of rust fungi, which enter plants via stomata (Koch et al. 1983). On wild-type plants, P. pachyrhizi invaded epidermal cells by forming an appressorium followed by a penetration hypha that grows into the lumen of the epidermal cell (Fig. 2B). Death of the penetrated cell was characterized by granulation of the cytoplasm and the accumulation of trypan-blue stain. (Keogh et al. 1980). In all the 28 different wild-type Arabidopsis accessions tested in this study, the fungus exited the epidermal cell but did not grow further, either inter- or intracellularly, into the mesophyll. In contrast to the wild type, pen3-1 epidermal cells did not always stain with trypan blue after penetration by $P$. pachyrhizi (Fig. 2C through F). In addition, independent of whether the penetrated epidermal cell stained with trypan blue, fungal growth proceeded intercellularly into the mesophyll tissue (Fig. 2E and F). There, cells around the hyphae displayed pronounced papilla formation (Fig. 2E), which also holds true for infection sites on the pen2-1/pad4-1 mutant (Fig. 2G). Fungal hyphae continued their growth in the intercellular spaces (Fig. 2F) and, in a few cases, formed haustorium-like structures in mesophyll cells (Fig. 2H). Together, the observed infection process and the infection structures discovered in Arabidopsis wild-type or pen3-1 mutant plants seemed to be similar to those known from the interaction of $P$. pachyrhizi with its soybean host (Koch et al. 1983). However, in all Arabidopsis genotypes tested, the fungus never sporulated, indicating that the NHR of Arabidopsis to $P$. pachyrhizi is determined after penetration, probably by inhibition of extensive fungal spread either into or within the mesophyll or both.

\section{Histochemical classification of interaction sites.}

To evaluate the development of $P$. pachyrhizi on various Arabidopsis mutants, interaction phenotypes were quantitatively assessed at the cellular level (Fig. 3). Leaves of infected Arabidopsis plants were harvested at the fourth day postinoculation (dpi) and were stained with trypan blue. For quantitative evaluation, we discriminated seven classes of interaction sites that encompassed pre- and postpenetration events. The first two classes included germinated spores without (class 1) or with (class 2) appressoria at the end of germ tubes but with no visible plant-defense reaction. Class 3 was defined by the pres- 
ence of papillae beneath the site of attempted penetration. Class 4 comprised epidermal cells that had undergone cell death, as determined by trypan-blue staining. In classes 5 and 6 , epidermal cells were trypan-blue stained and the fungus developed hyphae into the intercellular spaces of the mesophyll without (class 5) or with (class 6) trypan blue-stained mesophyll cells. Finally, interaction sites were observed at which mesophyll cells were stained with trypan blue but the penetrated epidermal cell was not (class 7).

\section{Quantitative assessment of single-cell interaction sites.}

Based on the above classifications, a clear picture emerged for fungal development on each Arabidopsis genotype (Fig. 3). Essentially, we did not observe significant differences between different accessions or mutants, either in the germination rate of uredospores or the formation of appressoria. Papillae formation as a defense response was mainly observed on plants without a pen mutation, e.g., Arabidopsis Col-0 and Col-3 gll. However, in about $60 \%$ of the interaction events between these two genotypes and $P$. pachyrhizi, fungal penetration into epidermal leaf cells caused a cell-death response (Fig. 3). No substantial fungal growth was observed in mesophyll tissue of Col-0 and Col-3 gll plants. This observation indicates the presence of an effective NHR mechanism in wild-type Arabidopsis. In contrast, fungal growth was observed in 30 and $40 \%$ of the interaction sites in the mesophyll of pen1-1 and pen2-1 mutants, respectively, and this was mostly associated with cell death in the epidermis. Basically, the same holds true for the pen1-1/pen2-1 double mutant (Fig. 3). Infections of pen3-1 by $P$. pachyrhizi resulted in a strong reduction in the number of infection sites at which fungal development was stopped shortly after the epidermis had been breached. Rather, in the pen3-1 mutant, $P$. pachyrhizi extensively colonized the mesophyll tissue. The latter was true for nearly $60 \%$ of the interaction sites, with $18 \%$ of the mesophyll cells undergoing cell death in response to fungal colonization (Fig. 3). This category of interaction sites was barely detected on pen 1-1 and pen2-1 mutant plants. Essentially, based on the microscopic analysis, the colonization of the pen2-3/pen3-2 double mutant resembled that of pen3-1. The same was true for the pen2-1/pad4-1 double mutant (Fig. 3).

Next, we investigated the progression of ASR development on Arabidopsis by recording the cellular interaction phenotype in leaves harvested at 1,4 , and $7 \mathrm{dpi}$. This revealed differences between genotypes as early as $1 \mathrm{dpi}$ (data not shown). While fungal hyphae were not found in the mesophyll of wild-type Arabidopsis plants up to $4 \mathrm{dpi}$, they were observed at $10 \%$ of the interaction sites by $7 \mathrm{dpi}$. However, at these sites, fungal growth was limited. In contrast, pronounced fungal mycelium was found as early as $1 \mathrm{dpi}$ in the mesophyll of mutant pen3-1 and pen 2-1/pad4-1. Notably, trypan-blue staining in the mesophyll was not observed until 4 dpi (data not shown).

\section{Single cell-interaction phenotypes between pen3-1 double mutants and ASR.}

The above results support a crucial role for PEN3 in controlling the NHR of Arabidopsis to $P$. pachyrhiza. However, even on pen3-1 mutants, fungal progression stopped after colonization of confined patches within the mesophyll. As a next step, we tested whether combined mutations in PEN3, and genes involved in well-described defense signaling pathways would compromise this mesophyll resistance. Specifically, we investigated the jarl-1 (jasmonic acid [JA] response) (Staswick et al. 1998, 2002) mutant of Arabidopsis, which is compromised in JA signaling. In addition, two mutants with defects in the salicylic acid (SA) signal transduction pathway have been included in the assay, i.e., sid2-1 (salicylic-acid deficient)
(Wildermuth et al. 2001) and eds1-2 (enhanced disease susceptibility) (Falk et al. 1999; Parker et al. 1996). Leaves of the single-mutant plants evaluated in this experiment did not differ from the wild type after inoculation with $P$. pachyrhizi (data not shown).

For microscopic analysis, inoculated leaves were harvested at 2 dpi and were subjected to trypan-blue staining. Cellular interaction phenotypes were categorized as described above. For simplicity, class 1 , which did not vary in proportion among the different host genotypes under investigation, is not shown in Figure 4. Furthermore, interaction sites with trypan bluestained epidermal cells and hyphal growth in the mesophyll (formerly classes 5 and 6) were combined in a single class. A high frequency (approximately 50\%) of interaction sites were observed on Col-0 plants at $2 \mathrm{dpi}$, in which the fungus had built an appressorium without causing any detectable staining
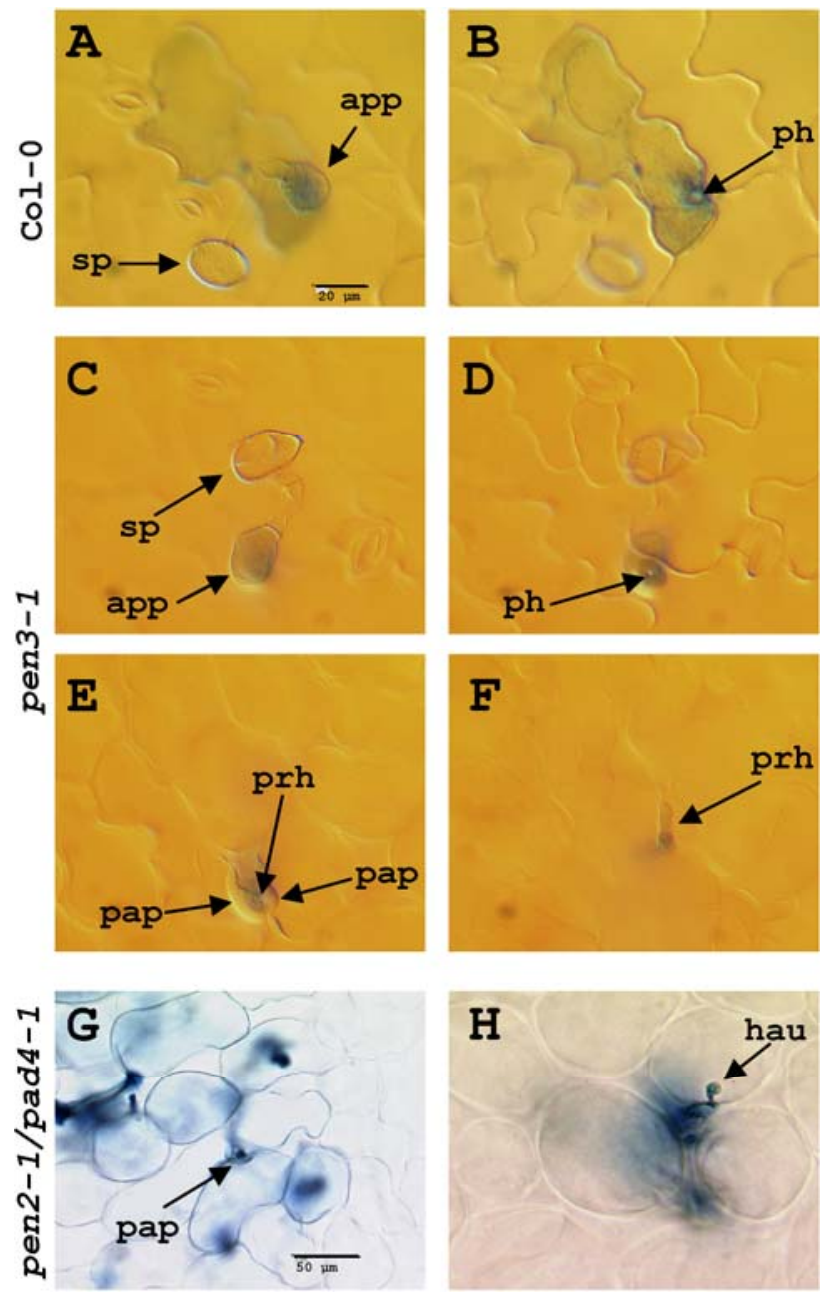

Fig. 2. Impaired basal defense in Arabidopsis mutants allows Phakopsora pachyrhizi to enter the mesophyll. $\mathbf{A}$ and $\mathbf{B}$, Infection sites were photographed at $1 \mathrm{~d}$ postinoculation (dpi) of Col-0 wild-type plants and $\mathbf{C}$ through $\mathbf{F}$, pen 3-1 mutants with uredospores. $\mathbf{G}$ and $\mathbf{H}$, Infection on mutant pen2-1/pad4-1 at 4 dpi. Leaves were stained with trypan blue before analysis with differential interference contrast (A through F) or bright-field $(\mathrm{G}, \mathrm{H})$ microscopy. Series of consecutive optical cuttings were made across particular infection sites starting with the focus on uredospores (A, $\mathrm{C})$, then moving stepwise through the epidermis (B, D), and finally to the mesophyll (E, F, G, H). Structures reminiscent of a haustorium were found on mutant pen $2-1 /$ pad4-1 $(\mathrm{H}) . \mathrm{sp}=$ uredospore, app = appresorium, $\mathrm{ph}=$ cross-section of penetration hypha in epidermal cells, pap $=$ papilla, prh $=$ primary hypha in the intercellular space of the mesophyll, and hau = haustorium-like structure. Nomenclature of infection structures was done according to Koch and associates (1983). 


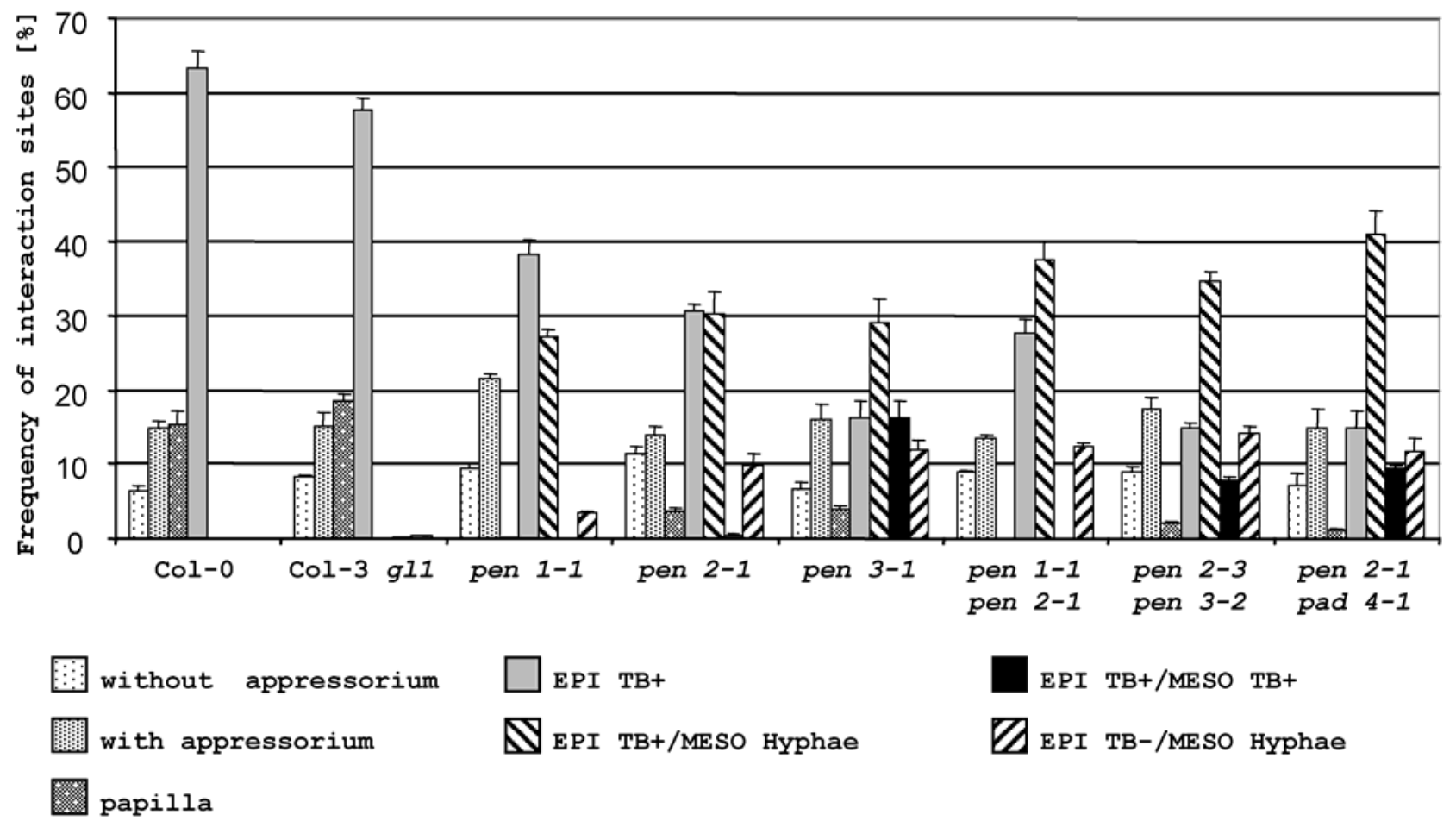

Fig. 3. Restriction of Phakopsora pachyrhizi growth on wild-type Arabidopsis plants correlated with high frequency of penetrated epidermal cells undergoing cell death. Quantitative assessment of single-cell interaction sites was done for wild-type and mutant Arabidopsis plants at 4 dpi. Thereby, seven classes of interaction sites were discriminated, whose frequency is given as the mean plus standard error per leaf. At least four leaves have been analyzed per genotype, and approximately 100 infection sites were inspected per leaf. The first class comprises spores that had germinated but failed to form an appressorium, the second class is represented by those forming an appressorium but without apparent penetration, the next classes describe plant defense reactions, i.e., formation of papilla, trypan-blue staining occurring in penetrated epidermal cells (EPI TB+), the simultaneous staining of epidermal and mesophyll cells (EPI TB+/MESO TB+), and increased hyphal growth in the mesophyll in combination with (EPI TB+/MESO Hyphae) or without (EPI TB-/MESO Hyphae) trypan-blue staining of affected epidermal cells.

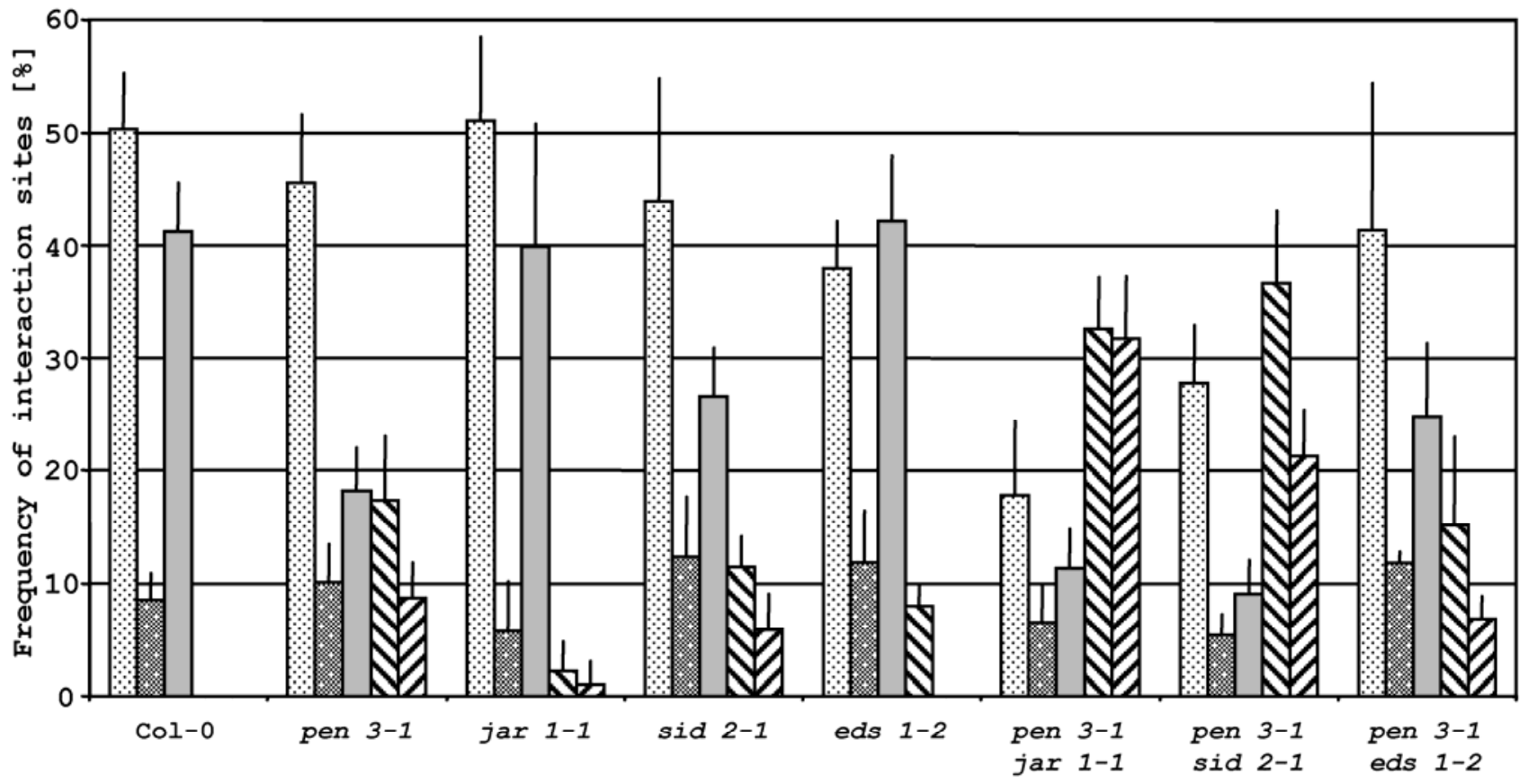

闻 with appressorium 0 papilla $\square$ EPI TB+ $\mathbf{\Delta}$ EPI TB+/MESO Hyphae $\boldsymbol{乙}_{\text {EPI TB-/MESO Hyphae }}$

Fig. 4. Concomitant knockout of pre- and postpenetration defense did not render Arabidopsis a host for Asian soybean rust. Wild-type Col-0, single mutant, or double mutant plants were harvested 2 days after inoculation with Phakopsora pachyrhizi. Interaction sites were grouped into different classes comprising sites at which spores had germinated and formed an appressorium and classes in which defense reactions appeared, i.e., formation of papilla, trypan blue staining occurring in penetrated epidermal cells (EPI TB+), staining of epidermal cells in combination with fungal growth in the mesophyll (EPI TB+/MESO TB), and increased hyphal growth in the mesophyll without trypan blue staining of affected epidermal cells (EPI TB-/MESO Hyphae). Frequencies are given as the mean plus standard error per leaf. At least three leaves have been analyzed per genotype, and approximately 30 to 50 infection sites were inspected per leaf. 
in the underlying plant tissue (Fig. 4). Obviously, the infection was still developing at $2 \mathrm{dpi}$, and the frequency of fungal penetration into epidermal cells further increased from 2 (Fig. 4) to 4 dpi (Fig. 3, with interaction sites numbering 15\% fewer than found in class 1). On wild-type Col-0 plants, $10 \%$ of the attacked epidermal cells countered penetration with papillae and $40 \%$ accumulated trypan blue beneath appressoria (Fig. 4). Essentially, microscopic investigation revealed no differences in the frequency of cellular interaction sites between wild-type Col-0 plants and jarl-1 mutant plants. When compared with Col-0, considerably more pathogen growth was found in mesophyll tissue of the eds 1-2 mutant, and a further increase was found in sid2-1 plants. Among the single mutants tested in this experiment, pen3-1 allowed the highest rate of fungal growth in the mesophyll tissue.

Next, we inoculated the double mutants pen3-1/jarl-1, pen3-1/sid2-1, and pen3-1/eds1-2 with $P$. pachyrhizi. Among these, the microscopic analysis revealed no substantial differences between pen3-1/eds1-2 double- and pen3-1 singlemutant plants (Fig. 4). Since both the pen3-1 and the eds 1-2 single mutants differ from the wild type but the double mutant did not display an additive effect, it could be concluded that effects of eds 1 and pen 3 mutations affect the same defense pathway. In contrast, the other double mutants showed enhanced colonization of the mesophyll by $P$. pachyrhizi when compared with pen3-1 plants. Mesophyll colonization could be estimated by adding the frequencies of the last three categories presented in Figure 4. Essentially, 65 and $58 \%$ of the interaction sites on the pen3-1/jarl-1 and pen3-1/sid2-1 mutant plants, respectively, affected the mesophyll, which was far more than that observed for the pen3-1 single mutant (26\%). Thus, we concluded that JARI and SID1 act synergistically with PEN3 in controlling ASR development on Arabidopsis. Of all the double mutants tested, the highest frequency of interaction sites with hyphae in the mesophyll but without trypan-blue staining in epidermal cells was found for the pen3-1/jarl-1 mutant. This may suggest that JARI contributes to cell death induced by $P$. pachyrhizi. Moreover, fungal colonization on this double mutant is speeded up as compared with the other genotypes, as evidenced by a lower frequency of class 1 interaction sites (Fig. 4).

Detection of $\mathrm{H}_{2} \mathrm{O}_{2}$ in Arabidopsis leaves infected with ASR.

To assay the potential involvement of $\mathrm{H}_{2} \mathrm{O}_{2}$ production in the Arabidopsis-ASR interaction, 3,3-diaminobenzidine tetrahydrochloride (DAB) staining was employed. We discriminated three types of DAB-associated plant responses: i) DAB coloration present in penetrated epidermal cells but absent from the mesophyll (Fig. 5A and B), ii) DAB coloration present in penetrated epidermal cells and the mesophyll (Fig. 5C and D), and iii) penetrated epidermal cells without but adjacent mesophyll cells with DAB coloration (Fig. 5E and F). The frequency of each of these categories was monitored on Col-0 or pen3-1 genotypes at 1 dpi (Fig. 5). Additionally, infection sites were counted that did not show DAB coloration in either the epidermis or in the mesophyll. We also counted infection sites at which penetration attempts resulted in the formation of a papilla. Thus, a total of five categories were measured quantitatively. Clear differences were observed between Col-0 and pen3-1 plants (Fig. 5). On wild-type Col- 0 plants, approximately $50 \%$ of the infection sites did not display any DAB coloration, while $40 \%$ of the infection sites showed coloration in penetrated epidermal cells. These percentages were very similar to those observed for the corresponding classes after trypan-blue staining (Fig. 3). DAB coloration of mesophyll cells occurred exclusively on pen3-1 mutants, in which it was associated with enhanced pathogen growth. Interestingly, $20 \%$ of the interaction sites showed DAB coloration in the mesophyll without coloration of the adjacent penetrated epi-
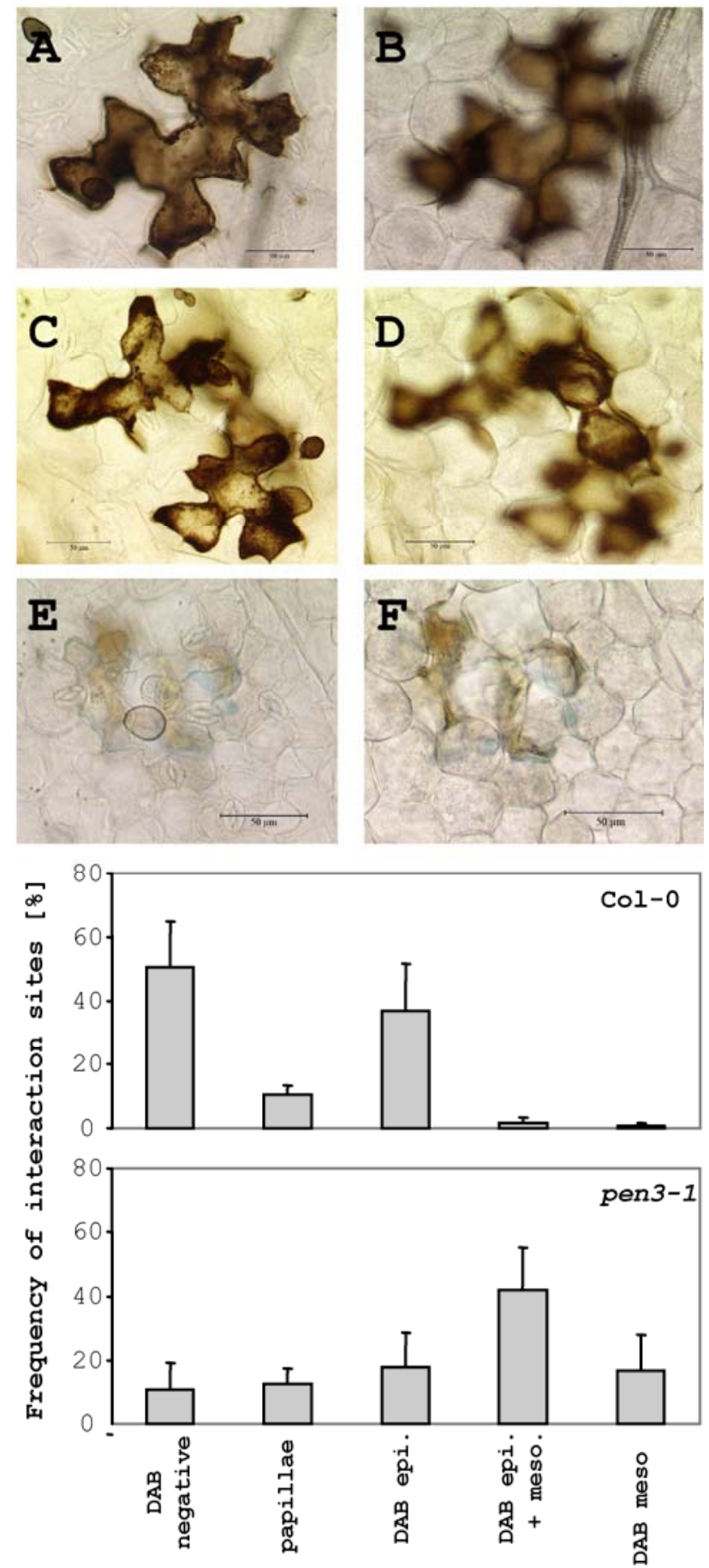

Fig. 5. Tissue-specific accumulation of $\mathrm{H}_{2} \mathrm{O}_{2}$ was correlated with arrest of Asian soybean rust on Col-0 wild-type and pen3-1 mutant plants. $\mathrm{H}_{2} \mathrm{O}_{2}$ accumulation was monitored by 3,3-diaminobenzidine tetrahydrochloride (DAB) staining of infected Arabidopsis Col-0 and pen3-1 leaves $24 \mathrm{~h}$ postinoculation (hpi) with bright-field microscopy. The upper panel shows six micrographs of infection sites $(\mathrm{A}-\mathrm{F})$ in which the focus was either on the epidermal cell layer (A, C, and $\mathrm{E}$ ) or on the mesophyll cell layer underneath (B, D, and F). A quantitative assessment of $\mathrm{H}_{2} \mathrm{O}_{2}$ accumulation in inoculated leaves of Col-0 or pen3-1 is presented in the two diagrams shown in the lower panel. Plant responses to formation of appressoria were classified in different categories: i) no detection of DAB staining (DAB negative), ii) fungal penetration was counterattacked by formation of papillae (papillae), iii) DAB staining solely in epidermal cells (DAB epi.), iv) DAB staining occurring concomitantly in epidermal and mesophyll cells (DAB epi.+meso.) and v) DAB staining only in mesophyll tissue (DAB meso.). Data were collected from 12 leaves from three independent plants per genotype, harvested at $24 \mathrm{hpi}$. A minimum of 100 interaction sites were inspected per leaf. Frequencies for each category are given as the mean plus standard deviation per leaf. 
dermal cells. Again, this was a striking similarity to the results obtained by trypan-blue analysis, in which also a considerable number of penetrated epidermal cells of Arabidopsis mutants did not accumulate dye, although the fungus spread into the mesophyll (Figs. 3 and 4).

Transcript accumulation in ASR-infected Arabidopsis plants.

The expression profiles of genes encoding for pathogenesisrelated $1 \mathrm{~b}(P R-1 b)$ protein and $P D F 1.2$ were investigated in Arabidopsis in response to a $P$. pachyrhizi infection (Fig. 6). Neither transcripts for $P R-1 b$ nor $P D F 1.2$ could be detected in noninoculated wild-type Arabidopsis plants (Fig. 6). $P R-1 b$ transcripts also did not accumulate after inoculation with $P$. pachyrhizi. By contrast, PDF1.2 transcripts accumulated by 24 h postinoculation (hpi) with $P$. pachyrhizi and their accumulation decreased during the next 2 days (Fig. 6).

Accumulation of $P R-1 b$ and $P D F 1.2$ transcripts upon inoculation with $P$. pachyrhizi was also measured in other Arabidopsis mutants (Fig. 6). Basically, noninoculated plants did not show detectable levels of transcripts for the two genes, except pen3-1, in which transcripts for both genes were found at 48 hpi. In mutant pen2-3/pen3-2, $P R-1 b$ transcripts accumulated weakly at 1 and 2 days after mock treatment (Fig. 6). Inoculation with $P$. pachyrhizi led to the accumulation of PDF1.2

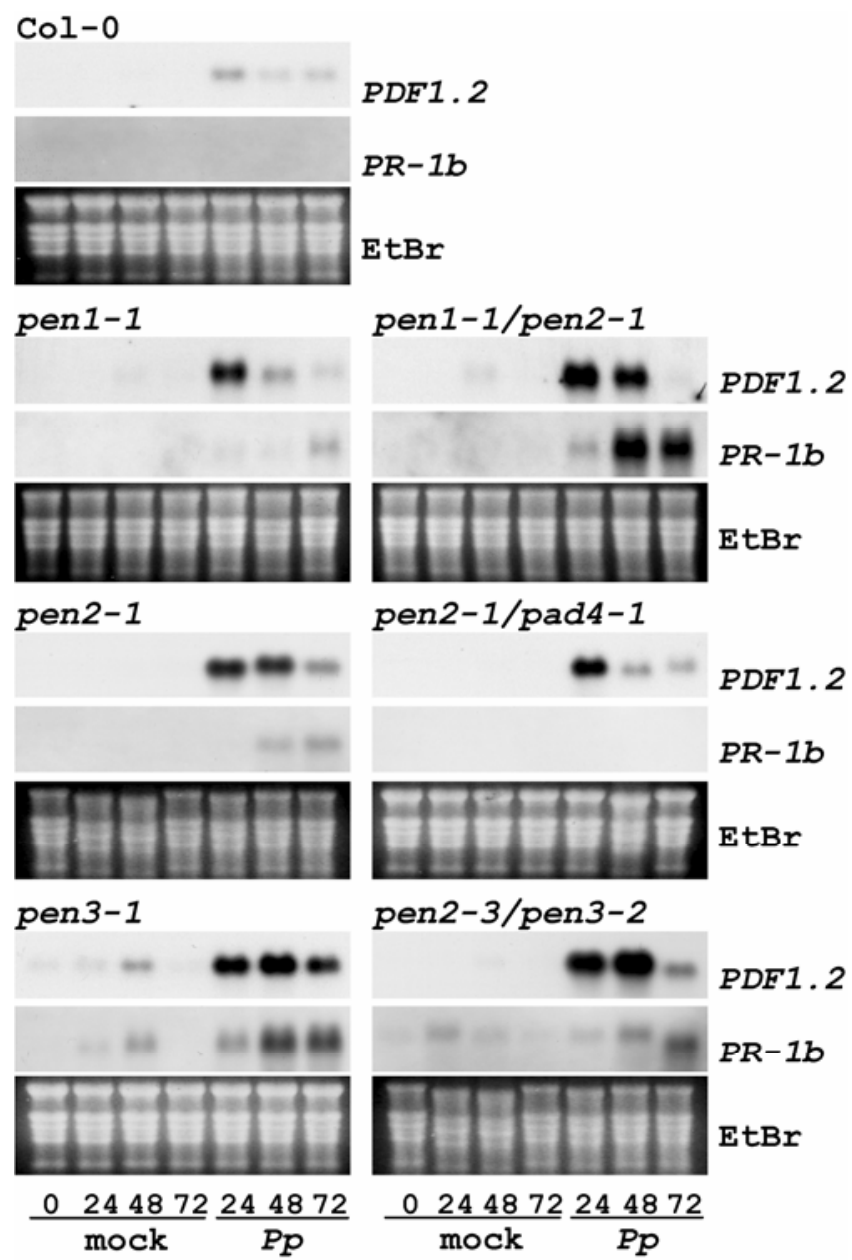

Fig. 6. Timecourse of accumulation of transcripts for $P D F 1.2$ and $P R-1 b$ showed an inverse responsiveness to infection with Asian soybean rust. Different Arabidopsis genotypes were infected with Phakopsora pachyrhizi, and noninfected plants served as a control (mock treatment). Total RNA was extracted from leaves harvested at timepoints indicated. RNA was subjected to RNA gel-blot analysis with gene-specific probes. Equal loading of RNA gels was confirmed after staining with ethidium-bromide (EtBr). transcripts in all mutants. $P D F 1.2$ accumulation in infected mutant plants was highest at 24 and $48 \mathrm{hpi}$ and declined subsequently. Strong accumulation of PR-1b transcripts was detected in pen3-1 single- and pen1-1/pen2-1 double-mutant plants after infection with $P$. pachyrhizi. Accumulation of $P R-1 b$ mRNA was highest at $72 \mathrm{hpi}$, and this profile correlated inversely with that observed for the accumulation of PDF1.2 transcripts (Fig. 6).

Accumulation of transcripts of the Arabidopsis gene NHL1O is considered to be a marker for cells undergoing a hypersensitive response (HR) (Zheng et al. 2004). Here, we tested whether NHL1O expression was triggered during ASR infection of Arabidopsis. Quantitative polymerase chain reaction (qPCR) analysis revealed a clear distinction between the genotypes tested (Fig. 7). Mock-inoculated pen3-1 mutant plants had accumulated NHL1O transcripts by 48 h. Significantly more NHL10 transcripts accumulated in ASR-inoculated pen3-1 than in the mock-inoculated controls. In contrast, NHL1O transcripts did not accumulate in mock- or ASR-inoculated Col-0 or pen2-1/pad4-1 plants.

\section{DISCUSSION}

Modern breeding programs for crops include the identification and optimization of effective and durable resistance traits. The so-called NHR response is particularly effective because it provides protection against all isolates of a pathogen species (Heath 2001). Due to this robust protection, NHR is being intensively studied as a source for resistance traits that might help in improving crop performance in the glasshouse and the field (Ellis 2006; Thordal-Christensen 2003).

NHR to rusts is typically mediated prior to formation of the first haustorium (Heath 1981). Our microscopic analyses with

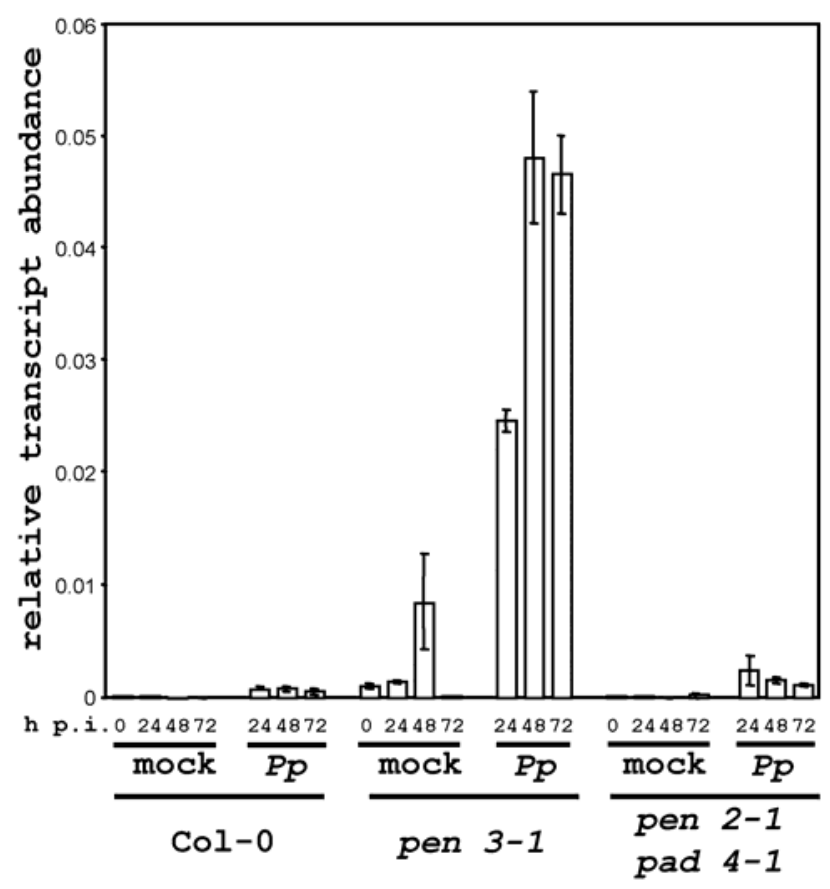

Fig. 7. NHL10 transcripts accumulated to high levels in pen3-1 after infection with Asian soybean rust. Leaves infected with Phakopsora pachyrhizi $(P p)$ and noninfected leaves (mock) were harvested at timepoints indicated. Relative abundance of NHL1O transcripts was determined using quantitative polymerase chain reaction and was calculated in relation to the constitutively expressed transcripts of actin2. RNA used in this analysis was from the same preparation as that used for RNA gel-blot analysis. Mean and standard error were calculated as described in Livak and Schmittgen (2001). 
Arabidopsis have shown that germination of $P$. pachyrhizi uredospores and the formation of appressoria were unaffected on this nonhost plant. Infection proceeded by formation of penetration hyphae that completely traversed penetrated epidermal cells, which concomitantly underwent a cell-death response, as evidenced by trypan-blue staining (Figs. 2 and 3). A similar abrogation of $P$. pachyrhizi development in the plant epidermis has been documented for other nonhost plants (Hoppe and Koch 1989). The authors reported that $P$. pachyrhizi never overcame the epidermal barrier, and it was concluded that collapse of epidermal cells might arrest fungal progress.

The involvement of reactive oxygen species in host-resistance and NHR responses of plants to pathogens has been extensively reviewed (Apel and Hirt 2004; Hückelhoven and Kogel 2003; Mehdy 1994; Nimchuk et al. 2003). Here, we demonstrated that $\mathrm{H}_{2} \mathrm{O}_{2}$ accumulated in approximately $50 \%$ of penetrated epidermal cells of wild-type Arabidopsis plants as early as 1 day after inoculation. This frequency further increased to $70 \%$ of penetrated cells during the second day of infection (data not shown). Levine and associates (1994) suggested that the accumulated $\mathrm{H}_{2} \mathrm{O}_{2}$ may orchestrate programmed cell death resulting in HR. This is consistent with our results, which show very similar but slightly time-shifted frequencies of penetrated epidermal cells that showed DAB coloration and trypan-blue staining (Figs. 3 and 5). However, rapid death of attacked epidermal cells may not lead to the complete arrest of fungal colonization, because this epidermal defense response also occurs on the susceptible soybean host (Koch et al. 1983). Hence, it seems that either the relative rates of initiation of epidermal HR or one or more unknown contributions of the mesophyll tissue might be crucial for the effectiveness of NHR in the Arabidopsis-P. pachyrhizi interaction. The latter seems more likely, because arrest of the fungus was manifested after it traversed the epidermal tissue and started to enter into the mesophyll (Fig. 2).

Since $P$. pachyrhizi is a direct-penetrating rust, we included Arabidopsis mutants with defects in epidermal defense in our studies. The pen 1, pen 2 , and pen3 genotypes have been reported to allow enhanced entry of nonadapted powdery mildew pathogens into the cell periphery (Collins et al. 2003; Lipka et al. 2005; Stein et al. 2006). As shown in this study, the three mutations led to enhanced invasive growth of $P$. pachyrhizi into the mesophyll (Fig. 3). On the basis of our results, it seems likely that there is an interplay of the respective wild-type alleles during the arrest of $P$. pachyrhizi in the epidermis of wild-type Arabidopsis. Among the pen-mutant plants we tested, the highest rate of mesophyll colonization was found on pen3-1, and cell death in the mesophyll was observed frequently. Mesophyll cell death also was associated with the resistance of a particular soybean host variety to ASR (Koch et al. 1983). However, this variety was not successful in the field. It was suggested that mesophyll cell death, most likely being initiated upon direct contact with haustorial mother cells or during haustorium initiation, presented the final barrier before irreversible establishment of disease (Hoppe and Koch 1989). Therefore, we conclude that a presumably first line of (nonhost) defense in wild-type Arabidopsis is shifted, due to the pen3-1 mutation, to the very last line of (host) defense. Similarly to the wild type, the majority of penetrated epidermal cells in the pen 1-1 and pen2-1 mutants underwent cell death (Fig. 3). However, in approximately half of these incidences, an increased rate of fungal hyphal penetration into the mesophyll was observed, as compared with the wild type. The pen 1-1 mutation showed a slightly lesser effect in this regard than the pen 2-1 mutant. This observation might be due to the fact that PEN1 has the highest impact on NHR against nonadapted powdery mildews, while PEN2 and PEN3 also control entry of other nonhost pathogens, as shown for Phytophthora infestans and Plectosphaerella cucumerina (Lipka et al. 2005; Stein et al. 2006).

On mutant Arabidopsis plants, a few interaction sites were found in which epidermal cell death was lacking even though fungal hyphae grew into the mesophyll (Figs. 3 and 4). It appears that cell death may have a dual role in interactions of potential hosts with $P$. pachyrhizi. Thus, it was suggested that ASR needs epidermal cell death to permit colonization of its soybean host (Koch et al. 1983), and if it is further assumed that epidermal cell death may contribute to the resistance of nonhost plants against ASR, it could be speculated that penetration and development in the mutant plants proceeded rapidly under these circumstances before epidermal cell death was triggered.

In the nonhost interaction between Arabidopsis and Erysiphe pisi, the simultaneous loss of two barriers conditioned by the PEN1 and PEN2 genes, namely resistance to penetration and postpenetration resistance, respectively, was sufficient to allow growth and asexual reproduction of the nonhost pathogen (Lipka et al. 2005). Similarly, in the work reported here, inoculation of the pen2-1/pad4-1 double mutant with P. pachyrhizi resulted in enhanced colonization by the pathogen when compared with the pen2-1 single mutant (Fig. 3). It could be speculated that the simultaneous knock-out of these two levels of resistance speeds up mesophyll colonization, which finally permits the formation of haustoria-like structures (Fig. 2H). However, the pathogen did not sporulate at these infection sites. Therefore, it must be concluded that establishment of a successful biotrophic interaction failed. To further analyze components involved in this block of compatibility, we took advantage of mutants with defects in SA or JA signaling. These two signal transduction pathways are known to contribute to resistance against biotrophic and necrotrophic pathogens, respectively (Glazebrook 2005; Thaler et al. 2004). Since it is clear that the effects of the postpenetration line of defense can only get visible after diminishing the penetration resistance, we conducted these experiments in a pen3-1 genetic background, i.e., using the double mutants pen3-1/jarl-1, pen3-1/ sid2-1, and pen3-1/eds1-2 (Fig. 4). Microscopic investigation suggested that the effect of EDS1 on ASR development is coupled to PEN3, while JAR1 and SID2 seemed to act synergistically with PEN3 (Fig.4). Since the effect of JARl becomes visible only in a pen3-1 genetic background, it could be speculated that JARl might be involved in postpenetration resistance. Nevertheless, neither the pen2-1/pad4-1 nor any of the pen3-1 double mutants supported growth of large fungal colonies or sporulation. This finding indicates a role for further, as yet unidentified, genes in controlling the NHR of Arabidopsis against $P$. pachyrhizi. Alternatively, it could be that essential requirements that are needed to establish the biotrophic stage of the pathogen are missing in Arabidopsis.

Arabidopsis-pathogen interactions are characterized by activation of distinct gene sets. Expression of the gene encoding PR-1b protein is widely thought to be a molecular marker for SA-mediated defense, while transcripts for plant defensin (PDF 1.2) accumulate strongly in JA-mediated resistance against nectrotrophs (Glazebrook 2001). RNA gel-blot analyses revealed a strong accumulation of PDF 1.2 transcripts in Arabidopsis mutants in comparison with the wild type after inoculation with $P$. pachyrhizi. Strikingly, transcript accumulation peaked coincidently with death of penetrated epidermal cells (Figs. 3 and 6). This finding was somewhat unexpected, because the plant defensin PDF1.2 was previously shown to accumulate in leaves of Arabidopsis upon challenge with necrotrophic fungi as a part of the JA- and ethylene-dependent defense mechanism (Glazebrook 2005). The fact that the osten- 
sibly obligate biotrophic fungus $P$. pachyrhizi triggered components of the JA pathway raised questions about whether this pathogen may, at least in parts of its life cycle, mimic a necrotroph. If this were correct, it could be speculated that $P$. pachyrhizi is able to survive in epidermal cells undergoing a celldeath response (discussed above), which has been proposed as a characteristic of necrotrophs (Mayer et al. 2001). However, the correlation of PDF1.2 expression with infections by necrotrophs seems not to be absolute, since transcripts also accumulated in Arabidopsis in response to infection with the nonadapted biotrophic barley powdery mildew fungus (Yun et al. 2003) but, interestingly, not after infection with the wheat powdery mildew fungus (Zimmerli et al. 2004). Thus, it seems that particular defense responses that are triggered during NHR do not depend on the (biotrophic or necrotrophic) lifestyle of the challenging pathogen but, rather, are a distinct response to a particular pathogen species. Indeed, there is evidence for specific recognition events in NHR to pathogens (Heath 2001; Matsumura and Tosa 1995).

In contrast to $P D F 1.2$, expression of $P R-1 b$, a reliable marker for activation of the SA-dependent resistance pathway, which is primarily involved in resistance to biotrophs, was detected at later stages of $P$. pachyrhizi infection in Arabidopsis mutants. $P R-1 b$ transcript accumulation occurred concomitantly with colonization of mesophyll tissue, an unquestionably biotrophic aspect of ASR etiology. Levels of JA and SA affect each other inversely (Spoel et al. 2003). Thus, an infection strategy that initially camouflages ASR's biotrophic lifestyle and does not trigger SA signaling might have advantages in establishing disease. This hypothesis was further supported by the finding that sid2-1 mutants, which are impaired in SAmediated resistance, were more frequently penetrated by $P$. pachyrhizi (Fig. 4). It could be hypothesized that the transcript profiles observed point to a widening of the pathogen's lifestyle, i.e., adopting or maintaining properties of necrotrophy, which might be one reason leading to a broader host range.

Mutations in the NDRl gene (non-race specific disease resistance 1) renders Arabidopsis susceptible to several strains of the bacterium Pseudomonas syringae pv. tomato and to the oomycete pathogen Hyaloperonospora parasitica (Century et al. 1995). NDRl shares homology to the tobacco HINl (harpininduced 1) gene, which was found to be up-regulated during the HR (Lee et al. 2001; Takahashi et al. 2004). However, among the 45 Arabidopsis genes that show sequence similarity to tobacco HIN1, only NHL10 (NDR1/HIN1-like) but not $N D R 1$ behaved like the tobacco gene by being up-regulated during the HR and in senescing leaves (Zheng et al. 2004). Interestingly, transcripts for NHL1O accumulated to high levels in Arabidpsis leaves of the pen3-1 mutant upon challenge with P. pachyrhizi (Fig. 7). Since expression of the gene, which could be considered as a potential marker for Arabidopsis tissue undergoing HR (Zheng et al. 2004), was neither triggered in wild-type Arabidopsis nor in the pen2-1/pad4-1 mutant upon ASR inoculation, it must be concluded that either the cell-death responses in these genotypes differ from those observed in pen3-1 or that signals that are required for NHL1O expression were negatively influenced by wild-type PEN3.

Our results differ from those reported in another recent study of the NHR of Arabidopsis against a nonadapted rust fungus from grasses (Puccinia triticina) (Shafiei et al. 2007). The authors tested a series of Arabidopsis mutants with defects in defense signaling, including single mutants tested in the present study, but none of the mutants tested displayed higher susceptibility to Puccinia triticina. This contrasts with a report on the infection of Arabidopsis with a nonhost dicot rust (Uromyces vignae) (Mellersh and Heath 2003). This pathogen was able to establish large fungal colonies on Arabidopsis mutants that were compromised in SA signaling. The differences between the two studies on stoma-penetrating rusts and our work presented here with the directly penetrating ASR made it obvious that NHR of Arabidopsis against rusts does not rely on a single mechanism. The same conclusion has been drawn before by Mellersh and Heath (2003). Moreover, our study demonstrated that the contribution of SA and JA in NHR cannot be predicted for a given fungal pathogen from its lifestyle without further investigation. Further studies will reveal whether the observed specificity in the NHR of Arabidopsis against $P$. pachyrhizi might lead to new concepts in our understanding of NHR.

\section{MATERIALS AND METHODS}

\section{Fungal and plant material.}

The isolate of $P$. pachyrhizi was taken from infected plant material collected in Brazil. The fungus was maintained on the susceptible soybean cultivar Pintada. Soybean seeds were germinated for 2 to 3 days in petri dishes at room temperature in the dark and were transplanted to a 2:1 mixture of soil (P-substrate, Balster Einheitserde $\mathrm{GmbH}$, Froendenberg, Germany) and sand. Plants were grown in a growth chamber at $22^{\circ} \mathrm{C}$, $60 \%$ relative humidity, and a photoperiod of $16 \mathrm{~h}$ at $133 \mu \mathrm{mol}$ $\mathrm{m}^{-2} \mathrm{~s}^{-1}$.

Arabidopsis seeds from wild-type Col-0 and mutant plants Col-3 gll (mutation in GLABROUS 1), pen1-1, pen2-1, pen31 , and double mutants pen $1-1 /$ pen $2-1$, pen $2-3 /$ pen $3-2$, and pen2-1/pad4-1 (Collins et al. 2003; Lipka et al. 2005; Stein et al. 2006) were provided by V. Lipka, Sainsbury Laboratory, Norwich, U.K. Double mutants pen3-1/jar1-1, pen3-1/sid2-1, pen3-1/pad4-1, and pen3-1/eds1-2 were provided by $\mathrm{P}$. Schulze-Lefert, Max Planck Institute for Plant Breeding Research, Cologne, Germany. Plants were cultivated in a growth chamber at short-day conditions. Arabidopsis accessions tested in response to $P$. pachyrhizi inoculation were as follows: Ag-0, Ak, Bay-0, Br-0, Bur-0, Can-0, Ct-1, Cvi, Cvi-0, Do-0, Eri, Fei-0, Ga-0, Gy-0, Kin-0, Kondara, Ll-0, Mt-0, Mz-0, Nd-1, Nok-3, Sha, Sorbo, Ts-5, Tsu-0, Van-0, Ws-0, Wt-5.

Uredospore suspensions for inoculation were generated by washing an infected primary soybean leaf in $50 \mathrm{ml}$ of $0.1 \%$ (vol/vol) Tween-20 in distilled water. After foliar spray application onto primary leaves of 16-day-old plants, these were placed in a dark moist chamber $\left(26^{\circ} \mathrm{C}\right.$ and nearly $100 \%$ relative humidity) for $24 \mathrm{~h}$. Afterwards, the plants were kept under growth conditions. Rust pustules were visible on infected plant material approximately 10 days after inoculation. Infected leaves were used as a source for inoculation after another 4 days. Fresh uredospores for inoculation were generated by removing old uredospores from infected leaves by shaking 1 day before spore harvest.

\section{Microscopic analysis.}

Infected leaves were harvested at the timepoints indicated and were stained with trypan blue (Keogh et al. 1980). After cutting, leaves were directly submerged in ethanolic lactophenol-trypan blue staining solution and were heated to $90^{\circ} \mathrm{C}$ for $3 \mathrm{~min}$. Leaf samples were cooled to room temperature for 10 min and were subsequently incubated in saturated chloral hydrate $\left(2.5 \mathrm{~g} \mathrm{ml}^{-1}\right)$ for a couple of days. During that time, chloral hydrate was changed several times, until leaves did not release blue stain anymore. Leaves were stored in $25 \%$ (vol/vol) glycerol. Fungal structures were inspected by Bright-field microscopy using a Leica DMRBE microscope (Leica, Bensheim, Germany). Images were taken with a digital JVC KYF 750 camera. Three to five leaves were analyzed for each genotype, and a total of 80 to 150 infection sites were inspected per leaf and timepoint. 


\section{DAB staining.}

$\mathrm{H}_{2} \mathrm{O}_{2}$ was visualized by applying a modified protocol of Thordal-Christensen and associates (1997). Leaves were harvested $24 \mathrm{hpi}$ and were incubated in DAB solution $(1.68 \mathrm{mg}$ $\mathrm{ml}^{-1}, \mathrm{pH} 3.8$ ) for $8 \mathrm{~h}$ under high humidity. During the incubation period, only the leaf petiole was in contact with the DAB solution. Therefore, the uptake of stain was driven by transpiration flow. Subsequently, leaves were fixed and cleared in saturated chloral hydrate $\left(2.5 \mathrm{~g} \mathrm{ml}^{-1}\right)$, were mounted in $50 \%$ (vol/vol) glycerol, and were examined by bright-field microscopy. Vacuum infiltration of DAB and $10 \mathrm{mM} \mathrm{H}_{2} \mathrm{O}_{2}$ was done as a control and confirmed equal distribution of peroxidases within leaves. Specificity of the staining was further confirmed by an enrichment of the DAB solution with $50 \mathrm{mM}$ ascorbic acid, which entirely inhibited accumulation of brown DAB precipitate in the presence of $10 \mathrm{mM} \mathrm{H}_{2} \mathrm{O}_{2}$ (data not shown).

\section{RNA gel-blot analyses.}

Total RNA was extracted using the acid guanidinium thiocyanate-phenol-chloroform protocol (Chomczynski and Sacchi 1987). For gel-blot analyses, $10 \mu \mathrm{g}$ of total RNA were separated on $1.5 \%(\mathrm{vol} / \mathrm{vol})$ formaldehyde agarose gels (Sambrook et al. 1989), were transferred to GeneScreen membranes, and were cross-linked using UV light (Amersham, Little Chalfont, U.K.). Equal gel loading was monitored by ethidium-bromide staining of the gel before RNA transfer. Membranes were hybridized according to Peterhänsel and associates (1998) in Dig Easy Hyb (Roche, Mannheim, Germany) at $65^{\circ} \mathrm{C}$ overnight with a fluorescein- or digoxygenin-labeled probe that was generated by in vitro transcription. After a stringent wash step at $60^{\circ} \mathrm{C}$ with $0.1 \times \mathrm{SSC}(1 \times \mathrm{SSC}$ is $0.15 \mathrm{M} \mathrm{NaCl}$ plus $0.015 \mathrm{M}$ sodium citrate), $0.1 \%$ sodium dodecyl sulfate (SDS), immunodetection of probes was done in combination with chemiluminescence detection using antifluorescein-Fab or antidigoxygenin-Fab fragments and CSPD (Roche, Mannheim, Germany). cDNAs used as the probes are designated PRIb (At2g14610) and PDF1.2 (At5g44420).

\section{qPCR.}

RNA $(1.25 \mu \mathrm{g})$ was incubated with $1 \mathrm{U}$ of DNAseI (Fermentas $\mathrm{GmBH}$, St. Leon-Rot, Germany) for $30 \mathrm{~min}$ at $37^{\circ} \mathrm{C}$, followed by a 15 -min enzyme inactivation step at $70^{\circ} \mathrm{C}$. OligodT primer (HindANCHORT 5'-AAG CTT TTT TTT TTT TTT T(AGC)-3') (1 pmol) was added, and the reaction mix was treated for $5 \mathrm{~min}$ at $70^{\circ} \mathrm{C}$. Reverse transcription was conducted for $1 \mathrm{~h}$ at $37^{\circ} \mathrm{C}$, using $100 \mathrm{U}$ of reverse transcriptase (Revert Aid M-MuLV, Fermentas GmBH). After enzyme inactivation for $10 \mathrm{~min}$ at $70^{\circ} \mathrm{C}$, first-strand cDNA synthesis was completed.

qPCR was conducted using an ABI PRISM 7000 sequence detector (Applied Biosystems, Darmstadt, Germany) and SYBR Green master mix (Invitrogen, Karlsruhe, Germany). First-strand cDNA reaction mix was diluted $1: 20$, and $2 \mu \mathrm{l}$ was subjected to PCR using AtNHL10-gene specific primers (1479F 5'-AAC GTT CCA AGG CCA AAA CC-3', 1531R 5'AAG TCC TAG ACT GTC CGG CGT-3') at a concentration of $0.5 \mu \mathrm{M}$ each. PCR-cycling conditions were implemented as follows: $2 \mathrm{~min} 50^{\circ} \mathrm{C}, 10 \mathrm{~min} 95^{\circ} \mathrm{C}$, followed by 40 repetitions of $15 \mathrm{~s}$ at $95^{\circ} \mathrm{C}$, and $1 \mathrm{~min}$ at $60^{\circ} \mathrm{C}$. Expression of actin was followed using gene-specific primers (2F 5'-GCT AAC ATT GTG CTC AGT GGT GG-3', 2R 5'-GGT GCA ACG ACC TTA ATC TTC AT- $3^{\prime}$ ) and served as an internal standard. The ABI PRISM 7000 SDS 1.0 program (Applied Biosystems) was used to analyze the results. The mean and standard deviation for the relative abundance of AtNHL10-specific transcripts were calculated according to the mathematical model of Livak and Schmittgen (2001).

\section{ACKNOWLEDGMENTS}

We thank V. Lipka (The Sainsbury Laboratory, Norwich, U.K.) for seeds of Arabidopsis mutant plants and for helpful discussions. We also thank P. Schulze-Lefert and R. Panstruga (Max Planck Institute for Plant Breeding Research, Cologne, Germany) for providing seeds of pen3-1 double mutants. We acknowledge continuous interest in this project by $\mathrm{M}$. Frank, H. Schultheiss, and T. Wetjen (BASF Plant Science, Agricultural Center Limburgerhof, Germany). A. J. Slusarenko is kindly acknowledged for critical reading of the manuscript.

\section{LITERATURE CITED}

Apel, K., and Hirt, H. 2004. Reactive oxygen species: Metabolism, oxidative stress, and signal transduction. Annu. Rev. Plant Biol. 55:373-399.

Assaad, F. F., Qiu, J. L., Youngs, H., Ehrhardt, D., Zimmerli, L., Kalde, M., Wanner, G., Peck, S. C., Edwards, H., Ramonell, K., Somerville, C. R., and Thordal-Christensen, H. 2004. The PEN1 syntaxin defines a novel cellular compartment upon fungal attack and is required for the timely assembly of papillae. Mol. Biol. Cell 15:5118-5129.

Bonde, M. R., Nester, S. E., Austin, C. N., Stone, C. L., Frederick, R. D., Hartman, G. L., and Miles, M. R. 2006. Evaluation of virulence of Phakopsora pachyrhizi and P. meibomiae isolates. Plant Dis. 90:708-716.

Century, K. S., Holub, E. B., and Staskawicz, B. J. 1995. NDR1, a locus of Arabidopsis thaliana that is required for disease resistance to both a bacterial and a fungal pathogen. Proc. Nat. Acad. Sci. U.S.A. 92:6597-6601.

Chomczynski, P., and Sacchi, N. 1987. Single-step method of RNA isolation by acid guanidinium thiocyanate-phenol-chloroform extraction. Anal. Biochem. 162:156-159.

Christiano, R. S. C., and Scherm, H. 2007. Quantitative aspects of the spread of Asian soybean rust in the southeastern United States, 2005 to 2006. Phytopathology 97:1428-1433.

Collins, N. C., Thordal-Christensen, H., Lipka, V., Bau, S., Kombrink, E., Qiu, J. L., Hückelhoven, R., Stein, M., Freialdenhoven, A., Somerville, S. C., and Schulze-Lefert, P. 2003. SNARE-protein-mediated disease resistance at the plant cell wall. Nature 425:973-977.

Ellis, J. 2006. Insights into nonhost disease resistance: Can they assist disease control in agriculture? Plant Cell 18:523-528.

Falk, A., Feys, B. J., Frost, L. N., Jones, J. D. G., Daniels, M. J., and Parker, J. E. 1999. EDS1, an essential component of $R$ gene-mediated disease resistance in Arabidopsis has homology to eukaryotic lipases. Proc. Nat. Acad. Sci. U.S.A. 96:3292-3297.

Glazebrook, J. 2001. Genes controlling expression of defense responses in Arabidopsis-2001 status. Curr. Opin. Plant Biol. 4:301-308.

Glazebrook, J. 2005. Contrasting mechanisms of defense against biotrophic and necrotrophic pathogens. Annu. Rev. Phytopathol. 43:205-227.

Harmon, C. L., Harmon, P. F., Mueller, T. A., Marois, J. J., and Hartman, G. L. 2006. First report of Phakopsora pachyrhizi telia on kudzu in the United States. Plant Dis. 90:380-380.

Hartman, G. L., Miles, M. R., and Frederick, R. D. 2005. Breeding for resistance to soybean rust. Plant Dis. 89:664-666.

Heath, M. C. 1981. Resistance of plants to rust infection. Phytopathology 71:971-974.

Heath, M. C. 1997. Signalling between pathogenic rust fungi and resistant or susceptible host plants. Ann. Bot. 80:713-720.

Heath, M. C. 2000. Nonhost resistance and nonspecific plant defenses. Curr. Opin. Plant Biol. 3:315-319.

Heath, M. C. 2001. Non-host resistance to plant pathogens: Nonspecific defense or the result of specific recognition events? Physiol. Mol. Plant Pathol. 58:53-54.

Holub, E. B., and Cooper, A. 2004. Matrix, reinvention in plants: How genetics is unveiling secrets of non-host disease resistance. Trends Plant Sci. 9:211-214.

Hoppe, H. H., and Koch, E. 1989. Defense reactions in host and nonhost plants against the soybean rust fungus (Phakopsora pachyrhizi Syd). J. Phytopathol. 125:77-88.

Hückelhoven, R., and Kogel, K. H. 2003. Reactive oxygen intermediates in plant-microbe interactions: Who is who in powdery mildew resistance? Planta 216:891-902.

Keogh, R. C., Deverall, B. J., and Mcleod, S. 1980. Comparison of histological and physiological responses to Phakopsora pachyrhizi in resistant and susceptible soybean. Trans. Brit. Mycol. Sci. 74:329-333.

Koch, E., Ebrahimnesbat, F., and Hoppe, H. H. 1983. Light and electronmicroscopic studies on the development of soybean rust (Phakopsora pachyrhizi Syd) in susceptible soybean leaves. J. Phytopathol. 106:302320.

Koch, E., and Hoppe, H. H. 1988. Development of infection structures by the direct-penetrating soybean rust fungus (Phakopsora-Pachyrhizi Syd) on artificial membranes. J. Phytopathol. 122:232-244. 
Lee, J., Klessig, D. F., and Nürnberger, T. 2001. A harpin binding site in tobacco plasma membranes mediates activation of the pathogenesisrelated gene HIN1 independent of extracellular calcium but dependent on mitogen-activated protein kinase activity. Plant Cell 13:1079-1093.

Levine, A., Tenhaken, R., Dixon, R., and Lamb, C. 1994. $\mathrm{H}_{2} \mathrm{O}_{2}$ from the oxidative burst orchestrates the plant hypersensitive disease resistance response. Cell 79:583-593.

Lipka, V., Dittgen, J., Bednarek, P., Bhat, R., Wiermer, M., Stein, M., Landtag, J., Brandt, W., Rosahl, S., Scheel, D., Llorente, F., Molina, A., Parker, J., Somerville, S., and Schulze-Lefert, P. 2005. Pre- and postinvasion defenses both contribute to nonhost resistance in Arabidopsis. Science 310:1180-1183.

Livak, K. J., and Schmittgen, T. D. 2001. Analysis of relative gene expression data using real-time quantitative PCR and the 2(T)(-delta delta C) method. Methods 25:402-408.

Matsumura, K., and Tosa, Y. 1995. The rye mildew fungus carries avirulence genes corresponding to wheat genes for resistance to races of the wheat mildew fungus. Phytopathology 85:753-756.

Mayer, A. M., Staples, R. C., and Gil-ad, N. L. 2001. Mechanisms of survival of necrotrophic fungal plant pathogens in hosts expressing the hypersensitive response. Phytochemistry 58:33-41.

Mehdy, M. C. 1994. Active oxygen species in plant defense against pathogens. Plant Physiol. 105:467-472.

Mellersh, D. G., and Heath, M. C. 2001. Plasma membrane-cell wall adhesion is required for expression of plant defense responses during fungal penetration. Plant Cell 13:413-424.

Mellersh, D. G., and Heath, M. C. 2003. An investigation into the involvement of defense signaling pathways in components of the nonhost resistance of Arabidopsis thaliana to rust fungi also reveals a model system for studying rust fungal compatibility. Mol. Plant-Microbe Interact. 16:398-404.

Mysore, K. S., and Ryu, C. M. 2004. Nonhost resistance: How much do we know? Trends Plant Sci. 9:97-104.

Nimchuk, Z., Eulgem, T., Holt, B. F., and Dangl, J. L. 2003. Recognition and response in the plant immune system. Annu. Rev. Genet. 37:579-609.

Ono, Y., Buritica, P., and Hennen, J. F. 1992. Delimitation of Phakopsora, Physopella and Cerotelium and their species on Leguminosae. Mycol. Res. 96:825-850.

Parker, J. E., Holub, E. B., Frost, L. N., Falk, A., Gunn, N. D., and Daniels, M. J. 1996. Characterization of eds1, a mutation in Arabidopsis suppressing resistance to Peronospora parasitica specified by several different RPP genes. Plant Cell 8:2033-2046.

Peterhänsel, C., Obermaier, I., and Rueger, B. 1998. Nonradioactive northern blot analysis of plant RNA and the application of different haptens for reprobing. Anal. Biochem. 264:279-283.

Rytter, J. L., Dowler, W. M., and Bromfield, K. R. 1984. Additional alternative hosts of Phakopsora pachyrhizi, causal agent of soybean rust. Plant Dis. 68:818-819.

Sambrook, J., Fritsch, E. F., and Maniatis, T. A. 1989. Molecular Cloning: A Laboratory Manual. 2nd ed. Cold Spring Harbor Laboratory, Cold Spring Harbor, NY, U.S.A.

Shafiei, R., Hang, C. U. I., Kang, J.-G., and Loake, G. J. 2007. Identification of loci controlling non-host disease resistance in Arabidopsis against the leaf rust pathogen Puccinia triticina. Mol. Plant Pathol. 8:773-784.
Spoel, S. H., Koornneef, A., Claessens, S. M. C., Korzelius, J. P., Van Pelt, J. A., Mueller, M. J., Buchala, A. J., Metraux, J. P., Brown, R., Kazan, K., Van Loon, L. C., Dong, X. N., and Pieterse, C. M. J. 2003. NPR1 modulates cross-talk between salicylate- and jasmonate-dependent defense pathways through a novel function in the cytosol. Plant Cell 15:760-770.

Staswick, P. E., Tiryaki, I., and Rowe, M. L. 2002. Jasmonate response locus JARI and several related Arabidopsis genes encode enzymes of the firefly luciferase superfamily that show activity on jasmonic, salicylic, and indole-3-acetic acids in an assay for adenylation. Plant Cell 14:1405-1415.

Staswick, P. E., Yuen, G. Y., and Lehman, C. C. 1998. Jasmonate signaling mutants of Arabidopsis are susceptible to the soil fungus Pythium irregulare. Plant J. 15:747-754.

Stein, M., Dittgen, J., Sanchez-Rodriguez, C., Hou, B. H., Molina, A., Schulze-Lefert, P., Lipka, V., and Somerville, S. 2006. Arabidopsis PEN3/PDR8, an ATP binding cassette transporter, contributes to nonhost resistance to inappropriate pathogens that enter by direct penetration. Plant Cell 18:731-746.

Stokstad, E. 2004. Agriculture-Plant pathologists gear up for battle with dread fungus. Science 306:1672-1673.

Takahashi, Y., Berberich, T., Yamashita, K., Uehara, Y., Miyazaki, A., and Kusano, T. 2004. Identification of tobacco HIN1 and two closely related genes as spermine-responsive genes and their differential expression during the tobacco mosaic virus-induced hypersensitive response and during leaf- and flower-senescence. Plant Mol. Biol. 54:613-622.

Thaler, J. S., Owen, B., and Higgins, V. J. 2004. The role of the jasmonate response in plant susceptibility to diverse pathogens with a range of lifestyles. Plant Physiol. 135:530-538.

Thordal-Christensen, H. 2003. Fresh insights into processes of nonhost resistance. Curr. Opin. Plant Biol. 6:351-357.

Thordal-Christensen, H., Zhang, Z. G., Wei, Y. D., and Collinge, D. B. 1997. Subcellular localization of $\mathrm{H}_{2} \mathrm{O}_{2}$ in plants. $\mathrm{H}_{2} \mathrm{O}_{2}$ accumulation in papillae and hypersensitive response during the barley-powdery mildew interaction. Plant J. 11:1187-1194.

Twizeyimana, M., Ojiambo, P. S., Ikotun, T., Paul, C., Hartman, G. L., and Bandyopadhyay, R. 2007. Comparison of field, greenhouse, and detached-leaf evaluations of soybean germplasm for resistance to Phakopsora pachyrhizi. Plant Dis. 91:1161-1169.

Wildermuth, M. C., Dewdney, J., Wu, G., and Ausubel, F. M. 2001. Isochorismate synthase is required to synthesize salicylic acid for plant defence. Nature 414:562-565.

Yun, B. W., Atkinson, H. A., Gaborit, C., Greenland, A., Read, N. D., Pallas, J. A., and Loake, G. J. 2003. Loss of actin cytoskeletal function and EDS1 activity, in combination, severely compromises non-host resistance in Arabidopsis against wheat powdery mildew. Plant J. 34:768-777.

Zheng, M. S., Takahashi, H., Miyazaki, A., Hamamoto, H., Shah, J., Yamaguchi, I., and Kusano, T. 2004. Up-regulation of Arabidopsis thaliana NHL1O in the hypersensitive response to cucumber mosaic virus infection and in senescing leaves is controlled by signalling pathways that differ in salicylate involvement. Planta 218:740-750.

Zimmerli, L., Stein, M., Lipka, V., Schulze-Lefert, P., and Somerville, S. 2004. Host and non-host pathogens elicit different jasmonate/ethylene responses in Arabidopsis. Plant J. 40:633-646. 